How to cite

Turner, J. J., Amirnuddin, P. S., \& Singh, I. H. S. (2019). University legal learning spaces effectiveness in developing employability skills of future law graduates. Malaysian Journal of Learning and Instruction, 16(1), 49-79.

\title{
UNIVERSITY LEGAL LEARNING SPACES EFFECTIVENESS IN DEVELOPING EMPLOYABILITY SKILLS OF FUTURE LAW GRADUATES
}

\author{
${ }^{1}$ Jason James Turner, Puteri Sofia Amirnuddin \& \\ Harmahinder Singh Iqbal Singh \\ Faculty of Business \& Law, Taylors University \\ Lakeside Campus, Subang Jaya, Selangor, Malaysia \\ ${ }^{\text {I} C o r r e s p o n d i n g ~ a u t h o r: ~ j a s o n j a m e s . t u r n e r @ t a y l o r s . e d u . m y ~}$
}

Received: 23 July 2018 Revised: 12 November 2018 Accepted: 2 March 2019

\begin{abstract}
Purpose - The objective of this study was to examine the role of legal learning space in a Malaysian university and how this space impacts on law students' preparation for the employment market. This study comes in response to the issue of inexperienced graduates, who lack appropriate employability skills for the world of work, commonly referred to as the 'graduate skills gap'.
\end{abstract}

Methodology - This study used an online survey (accessed via a QR code) on 256 law students at a university in Malaysia. The sample size comprised 213 currently enrolled students and 43 alumni, with the former cohort representing $95 \%$ of the total law student population at the university and the latter representing $17 \%$ of the total alumni population.

Findings - The study found that students, regardless of their year of study, did not consider that legal learning space at the university replicated real life legal practice but thought that the space prepared them for employment. The students felt that some legal learning 
space was better than others in developing their employability skills. Despite this they enjoyed interacting in the space collectively and felt that it helped them improve their teamwork, communication and soft skills. It also revealed that the perceptions of legal learning space could be improved with better management of staff and student expectations.

Significance - This study was one of few studies, which investigated the role of learning space in developing law students' employability skills set. The findings helped to consolidate existing research in the area of graduate skills gap, the development of graduate employability skills, and in advancing research on identifying students' perception of learning space and the specific skills students felt they had developed while engaged in this space. This study will be of particular interest to both employers and universities as they seek to manage each other's expectations and pursue a more practice-based learning curriculum.

Keywords: Legal learning space, law students, graduate skills gap, employability skills.

\section{INTRODUCTION}

Over the past few decades, law faculties have received criticisms that many law graduates are unable to perform competently at the workplace (Batt, 2015; Trail \& Underwood, 1996). Although law faculties emphasise 'holistic learners' and 'practice-ready' graduates, they continue to face the fundamental question on how law faculties address the 'graduate skills gap' so that law students enter the employment market as competent lawyers. On the one hand, we have the argument that law schools overemphasise knowledge and mastery of the technical aspects of legal rules (Gurpur \& Rautdesai, 2014). On the other hand, there is the argument that legal education should develop more than students' interpretative skills and instead familiarise them with meaningful engagements in practice (Babcan \& Babcan, 2015; Rubenson, 2005). Despite this debate, there is a lack of consistency in how educational establishments address the issue of providing appropriate legal learning and the necessary learning space to address the graduate skills gap. Many universities do not integrate skills and practice in a way which allows law students to 
understand and prepare themselves to meet employers and clients' needs.

This study aims to examine the role of legal learning space in a Malaysian university and how this simulated work environment can enable law graduates to be suitably prepared for the employment market, which is arguably becoming increasingly disruptive and unpredictable. The study consolidates and advances research in the area of how learning space or platform affects law students' preparedness to join the profession (Batt, 2015; Daley \& Sequeira, 2018; Harrop \& Turpin, 2013; Rosenbaum, 2014; Stuckey, 2007; Sullivan, et al., 2007) by providing a simulated learning environment beyond theoretical knowledge whereby law students can emulate the role of practising lawyers as closely as possible (Batt, 2015; Rosenbaum, 2014; Stuckey, 2007; Sullivan et al., 2007).

\section{LITERATURE REVIEW}

Today's graduates are likely to be impacted by the disruptive employment market. On the one hand, new jobs and opportunities will be created but on the other hand, there will be unemployment and downsizing of positions. To this end, the graduate employability skills set needs to reposition itself from being technically focused, to being more socially sensitive (Kahn, 2017; National Center for O*NET Development for USDOL, 2017). In response to changes in the employment market many universities have attempted to disrupt their academic programmes by incorporating creativity, problemsolving, interaction with technology, handling of data and emotional intelligence (Gosh, 2017; Jameson, et al., 2016; Knemeyer, 2015; Stigliani, 2017). Such changes were designed to further enhance employability-led curricula which included collaborative learning space, work-based learning (WBL), internships, business simulations and real-world experience (Chillas, 2014; Galloway, Marks, \& Chillas, 2014; Kolb \& Kolb, 2005, 2010; King \& Newman, 2009; Renganathan, Karim, \& Li, 2012; Turner, et al., 2018; Yusof, Awang-Hashim, \& Kian, 2016; Vos \& Brenan, 2010). All these initiatives implemented by universities were designed to improve the learning experience of students, their employability, and develop their hard and soft skills sets. The hard skills involved teamwork, project management, leadership, creative thinking and problem- 
solving with communication considered to be both a hard and soft skill (Department for Business Innovation \& Skills, 2015; Draycott \& Rae, 2011; Fiala, Gertler, \& Carney, 2014; Jones \& Iredale, 2010; Turner \& Mulholland, 2017;). In contrast, the soft skills encompassed confidence and self-reflection (Beard, Schwieger, \& Surendran, 2007; Clarke, 2016; Jameson, et al., 2016; Rao, 2013, 2014, Sail \& Alavi, 2010).

\section{Learning Space at Universities}

The focus of this study is on the role of learning space and its capacity to prepare law students for employment and to develop their employability skills. The most prominent law faculties in Malaysian tertiary education are equipped with various learning spaces to provide arguably the most appropriate learning experience for their students (Babacan \& Babacan, 2015). Some examples of learning space available at typical Malaysian universities counting this university, which is the focus of this study includes moot courts, legal aid centres, and libraries. However, the learning space at the university in this study has expanded beyond those available at other institutions to include collaborative classrooms with lecture capture and augmented reality learning space. Despite this, having appropriate learning space does not necessarily make a law student more work ready (Batt, 2015). It simply creates an environment for learning and the practical application of knowledge, with some learning space better than others at cultivating this learning. There is also the aspect of the cumulative effect where the more the learning space is made available for practical applications, the more likely it will better prepare students for the world of work. However, this perception only works if it is both appropriate and complementary to the students' learning experience.

\section{Moot Court}

Moot courts are generally considered an attractive learning space for law students, although there is a 'challenging' feel attached to the room. In many law faculties, moot courts play an important role in providing law students with a degree of exposure to practice, albeit in a simulated fashion. As early as the 1890s, moot courts were an important space for the learning of law, where students prepared briefs and argued cases (Joy, 2018). Mooting is essentially 
a law school activity conducted in a moot court which requires participating students to analyse and argue both sides of an appeal from a fictitious lawsuit before law lecturers and/or lawyers who serve as judges (Bucholtz, Frey, \& Tatum., 2002; Teply, 2003). Many law faculties instruct students to participate in mooting as a requirement for graduation and some law faculties even offer moot court engagements as part of their module experience and assessment, tasking the student to collate case law, read statutes, prepare submissions, improve legal writing and participate in a moot (Rajeswaran, 2006). There are also moot competitions held in moot courts organised by universities, law firms, governmental agencies, and organisations in the Asian region, at both national and international levels, which underline its importance to the student learning experience (Rajeswaran, 2006).

A university's integration of mooting in the academic curriculum is argued to assist students in sharpening their advocacy skills and to have in-depth knowledge of the subject matter and the law. But it is not only their legal skills which can be developed, a moot court can also enhance students' persuasive skills, develop their ability to communicate effectively, organise themselves better, enhance their ability to research and write and improve their level of confidence (Taylor, 2015). The argument that the activity of 'mooting' in a moot court can help develop students' hard and soft skills is supported by Krupová, Pošíková, Friedel, \& Potucký (2013) who argued that mooting develops logical thinking, analytical and rhetorical skills, and the ability to perform in public. Students are encouraged to think on their feet in this learning space and to respond quickly when questioned by a panel of judges. Similar to the real appellate court environment, students will be observed by an audience sitting in the viewing area giving them a realistic experience, which includes having to deal with their emotions (Krupová et al., 2013). In a moot room environment, the judges on the panel are free to interrupt the student while presenting, to ask questions about the facts of the case enabling the student to learn to anticipate difficult questions about his/her legal position and to respond intelligently in a persuasive manner, albeit in a simulated environment.

A moot court however must be utilised effectively and be appropriately integrated into the module and programme learning approach with staff and students well briefed on its use and 
usefulness if it is to facilitate student learning and to address the employment skills gap. In some universities, moot court is simply used as a classroom. In other instances, the experience of mooting may have a negative impact on students when the panel of judges provide destructive instead of constructive feedback on students' oral arguments resulting in students receiving a negative experience and being intimidated to practise law in the future.

\section{Legal Aid Centres}

Legal aid centres provide an educational space for law students to bridge the gap between the theory taught in class and its practice (Lawton, 2017) and in recent years, there has been an increase in the establishment of legal aid centres in universities. Law faculties have added legal aid centres to provide legal services and legal assistance to disadvantaged communities who have limited access, predominantly because of financial restrictions (Rosenbaum, 2014). Having legal aid centres in a university enables students to gather experience with real clients and with real legal problems within the supportive university environment, under the supervision of practising lawyers and lecturers. The advice provided is usually oral advice and would be limited to areas of law within the scope of the legal aid centres such as consumer protection matters relating to landlord and tenancy, financial services, family law, employment and others.

The exposure to real life problems through the legal aid centres should enhance students' awareness of issues relating to lawyer/ client engagements (Trail \& Underwood, 1996) and are becoming widely accepted by law faculties as a platform to train students to develop their skills in providing legal advice. The skills gained by law students include counselling, negotiation and research skills. These skills complement the hard and soft skills developed on moot court and enhance their preparedness for employment.

However, one common problem associated with legal aid centres is the failure of the law faculty to monitor or assess the students' learning experience. Given the fact that legal aid centres do not form part of the curriculum, students' learning experience varies from one another depending on the type of clients or cases and how the lawyers, supervisors or lecturers review the students' performance at the centres (Trail \& Underwood, 1996). There is also the argument that legal aid centres do not actually teach law students how to think 
critically about justice or rather it teaches them to empathise with a client and offer an emotional response (Breen, 2005). While it is meritable to develop students' softer skills set, through exposing them to the fluid context of practising law, the experience would be most valuable when it is a structured experience, appropriately monitored and measured by legal peers (Trail \& Underwood, 1996).

\section{Library}

This remaining learning space supports the work of the two main practice based space, the moot court and the legal aid centre, and contributes to the overall experience of the programme. Underpinning a graduate lawyer's skills set is knowledge of the law, predominantly gained through studying legal cases and statutes from the library. Most universities in Malaysia have libraries, which are fit-for-purpose, and able to cater to students' learning needs. The libraries provide a variety of learning space for law students to become engaged with literature (Wilders, 2017; Pennington, 2012) and to connect to the virtual world, collaborate virtually and physically, and have a sense of community (Cunningham \& Tabur, 2012; Ellison, 2016; Lippincott, 2010; Seal, 2015). Law students are able to develop a good set of research skills through this independent and collaborative learning while conducting legal research in the library (Sullivan, 2010), which will prove beneficial to them at the workplace.

However, there are some limitations regarding the libraries in Malaysian universities and their ability to enhance the learning experience of students and prepare them for the workplace. As mentioned, the majority of university libraries are relatively well equipped but not all. The challenges for university libraries are to stay current which can prove to be both costly and time-consuming (Baker, 2017). A lack of appropriate library facilities could negatively impact on students' preparedness to enter the workplace, based on their level of familiarity and the level of understanding their employers have with regard to the latest technology. The learning space offered by the library impacts on students' learning experience and if access to the space is hindered, students may lose the opportunity to develop their group working skills in a structured way, skills which include resolving conflicts amongst team members, appreciation of diversity, leadership and showing empathy and support for team members. This study is not stating that without such learning space these skills would not be developed, rather, the lack of access to such space may 
cause students to work individually or in groups in an ad hoc manner, which could result in such skills not being fully developed.

\section{Supportive Learning Space - Collaborative Classrooms and Lecture Capture Classrooms}

While many classrooms for students studying law still feature the one-way communication flow with an academic who lectures and students taking notes, there have already been changes to the teaching and learning approach of universities and the skills requirements of employers. In other words, there is currently a potential mismatch between student experience, expectations of employers and the employment market. This is why collaborative learning space such as 'The X-Space classrooms' (Ng, Lim, \& Nair, 2014) and lecture capture classrooms (Ruan, 2014) have been introduced at the university which is the focus of this study and is arguably more appropriate to the new generation of learners. The use of collaborative learning settings such as X-Space classrooms have the capability to develop law students' creativity and confidence and to prepare the students to take charge of discussions and conduct meetings with team members and/or clients at the workplace (Matamoros, 2015). The recorded lecture capture classrooms, in contrast, offer students the opportunity to watch and replay lectures to assist in their understanding and capacity to reflect (Bender, \& Hassall, 2014; Danielson, et al., 2011; Joseph, et al., 2018; Witton, 2017). Other pedagogical benefits on the use of lecture capture include increased student satisfaction, active control over learning, increased accessibility to non-native English language speakers and the ability to generate more detailed notes (Newton, et al., 2014).

Although the X-Space and lecture capture classrooms can aid students' retention and understanding of legal concepts, the learning experience does have its limitations in terms of the role it plays in the programme learning experience. For example, some law students may prefer the more conventional teaching and learning style where they take notes in the classroom and therefore, the availability of lectures via the lecture capture system may deter students from attending classes (King, et al., 2017). An appropriate balance and complementary use of learning space is a theme to emerge from this study as poorly devised learning space and a lack of understanding of its role in the learning environment could dilute the impact of this learning environment and reduce rather than enhance the employability of graduates (Bos, et al., 2015). 


\section{Augmented Reality Learning Space}

Given the fact that law practices operate in a disruptive market where work and the required skills set of graduates are changing, the introduction of technology to the teaching and learning experience becomes increasingly important to prepare graduates for employment (Clarke, 2009; Mangan, 2017; Schwab, 2016; Scott, 2015; Singh, Narasuman, \& Thambusamy, 2012). There is an argument that Artificial Intelligence (AI) in particular could replace tasks currently performed by humans (Hensler, 2018; Nokelainen, Nevalainen, \& Niemi, 2018; Oskamp \& Lodder, 2006), and therefore graduates need to develop their understanding of technology and their softer skills to remain employable (Forum, 2016). Development of softer skills had been discussed earlier in moot rooms, legal aid centres and libraries but in terms of technology, many universities only incorporate basic level technology in libraries and classrooms. The use of augmented reality (AR) as a learning space allows students to combine virtual data with the real environment to learn law outside the classroom (Azuma, 1997; Carmigniani \& Furht, 2011; Klopfer \& Squire, 2008). The use of AR in learning law encourages law students to explore online resources to resolve issues in the real world which in turn develop their problem-solving, critical, cognitive and independent learning skills (Amirnuddin, 2018; Serin, 2017). Studies have also shown that the use of AR supported with multimedia materials can assist students' learning process to make learning enduring (Fitzgerald, et al., 2008). Through their engagement in this technology, when students enter the workforce, they can bring their understanding of the technology into the workplace besides the opportunity to display their creativity and good sense of imagination which could benefit employers by way of providing new perspectives to legal problems. However, given the fact that law students are used to conventional assessment methods namely written assignments and final examinations, there could be resistance from some students to AR learning space. AR could be perceived as a novelty with students losing interest in the platform after one modular engagement. Lapses in connectivity and technology breakdowns could also lead students to question the value of AR. Therefore, it is important to be cautious in integrating technology into the learning experience. It has to add value and not simply repeat the learning provided elsewhere or be perceived as a needless add-on. 
There has been some research on learning space (Elyna \& Pitt, 2014; Yusof et al., 2016) and in the context of the law, both collectively (Batt, 2015) and through assessments of individual components such as mooting (Krupová et al., 2013) and legal aid centres (Lawton, 2017; Trail \& Underwood, 1996). This study however is limited and there are gaps particularly in the areas of future technologies, for example AR and the role learning space play in developing graduates' employability skills set. These gaps in the current literature will be partially addressed by this study including its examination on how learning space is perceived by law students and the role it plays in developing graduate employability skills and preparing them for the world of work.

\section{METHODOLOGY}

This study used a self-completed online questionnaire, which took approximately 3 minutes to complete, with a total of 256 respondents, which included 213 law students from the first, second and third year and 43 law alumni at a university in Selangor, Malaysia in May 2018. The design of the questionnaire was based on the literature, specifically previous studies on legal learning space (Babacan \& Babacan, 2015; Rosenbaum, 2014; Stuckey, 2007; Sullivan et al., 2007) and graduate employability skills (Clarke, 2016; Jameson et al., 2016; Rao, 2013; Turner \& Mulholland, 2017), and it used a QR code as a unique way to encourage students to participate and complete the questionnaire via their mobile devices. The use of a QR code proved successful with the sample of 213 respondents which represented $95 \%$ of the total available law student population at the university and underlined the representativeness of the cohort (Malhotra \& Birks, 2006).

This study incorporated a mixture of five point Likert scale questions, with the response categories ranging from strongly agree to strongly disagree, and open-ended qualitative questions. The questions were derived from the literature with the Likert scale questions allowing for "an expression of intensity of feeling" (Churchill, 1991, p. 425) and focused on perceptions of specific learning spaces at the university and how effective they were in replicating the reality of legal practice and developing their hard and soft employability skills. With regard to the open-ended questions, the focus was on eliciting a "rich and detailed description" (McGivern, 2003, p.34) 
from respondents in terms of "what they, uniquely, have to offer by way of information, experiences, feelings, images, attitudes, ideas and so on" (Kent, 1999, p. 75), i.e. perceptions of what they enjoyed most and least about the learning space.

The quantitative results were analysed using a series of Spearman's Rho tests to understand the relationship between legal learning space and employability skills, multiple-regression to test for the significance of the variables: age, gender and stage of academic development and a Mann-Whitney U test to compare the responses between alumni and non-alumni students. The qualitative results were analysed using content analysis, to enable the categorisation of content around key themes so as to assist the researchers to understand the rationale behind the respondents' perceptions on legal learning space.

To ensure that this study was both reliable and valid, a pilot study was conducted with five students. The pilot study confirmed the clarity and appropriateness of the questions, and the respondents' interpretation of the reasoning behind the type of questions used, the order of the questions and the scale used (Zikmund, 2003). In order to measure the internal consistency of the online survey, a Cronbach's alpha coefficient was used. The test revealed a figure of 0.961 , which represented a good scale and valid test model (Malhotra \& Birks, 2006).

\section{RESULTS}

In terms of the respondents' demographics, 177 (69.1\%) were female and $78(30.5 \%)$ were male with one $(0.4 \%)$ individual indicating that he/she preferred not to reveal his/her gender. The majority of the respondents were aged between 18 and 23, with $123(48 \%)$ aged between 18 and 20, 108 (42.2\%) aged between 21 and 23, 22 (8.6\%) aged between 24 and 26 and $3(1.2 \%)$ aged between 27 and above. All respondents were studying law, across year of study with the majority (64\%) from the first year, 39\% from the second year and 9\% from the third year. The reason for the difference in numbers was the student intake, 136 students from the first year, 83 students from the second year and 19 students from the third year, with the numbers representing $95 \%$ of the total available law student population at the university. The study also included 43 alumni, which represented 
$17 \%$ of the total alumni population, to see if the perceptions of graduated students were any different from those who were currently studying. Although comparing 213 current law students with 43 alumni was not expected to reveal significant differences, which indeed was the case following a series of Mann-Whitney $U$ tests, there was a slight tendency for alumni respondents to agree with and be less neutral to statements relating to learning space. We could not conclude, however, that having been exposed to all types of learning space made alumni respondents more likely to agree and strongly agree to these particular statements. This comparison does however warrant further investigation and will form part of a future mixed method study on the role of learning space and the preparedness of students (from across academic disciplines) for employment.

\section{Preparation for the employment market}

To investigate respondents' perceptions of their course and the role it plays in preparing them for the employment market, a series of questions were asked which revealed reasonably high levels of agreement to statements but with a degree of neutrality (Table 1). The variables: age, gender and stage of academic development were tested for significance using multiple regression however, none proved significant.

Table 1

Statistics relating to student perception of their law course and preparation for employment

\begin{tabular}{lccc}
\hline \multicolumn{1}{c}{ Question } & $\begin{array}{c}\text { Strongly agree/ } \\
\text { agree }(\%)\end{array}$ & $\begin{array}{c}\text { Neutral } \\
(\%)\end{array}$ & $\begin{array}{c}\text { Strongly disagree/ } \\
\text { disagree }(\%)\end{array}$ \\
\hline $\begin{array}{l}\text { I feel that my } \\
\text { university law course } \\
\text { has prepared me for } \\
\text { the future employment } \\
\text { market }\end{array}$ & $66.8 \%$ & $22.7 \%$ & $10.6 \%$ \\
\hline $\begin{array}{l}\text { I feel that my } \\
\text { university law course } \\
\text { has developed the } \\
\text { skills I need to secure } \\
\text { employment }\end{array}$ & $69.5 \%$ & $23.4 \%$ & $7.1 \%$ \\
\hline
\end{tabular}


The majority of the respondents felt that their law course prepared them for the employment market and developed the skills they required to secure employment. However, their level of agreement to statements was not particularly high, as $22.7 \%$ of the respondents chose to be neutral. The reasons for this moderately high level of agreement could be because they had not yet experienced being employed and therefore did not know if they were prepared. This argument would be less plausible if the respondents had undergone internships in law firms during their studies and therefore understood the requirements of the employment market. However, the majority of the respondents in this sample had not undertaken internships and therefore this could be one of the reasons for such responses. It was equally likely that some respondents felt that the law course could help them engage more with industry and be more representative of the legal environment which was reflected in some of their qualitative comments which will be discussed later in the context of legal learning space. A comparable trend could be observed, in terms of the employability skills developed during their law course which is of a similar level of neutrality (23.4\%) and a slightly higher level of agreement. Similarly, with reference to the first statement, it could be argued that respondents did not know the skills they require to secure employment due to a lack of appropriate work experience and knowledge. It could also be argued that respondents were unsure if the programme developed their employability skills. When we examine the responses to learning space and its relationship with specific hard and soft employability skills, we will have a better understanding of the reasons behind these moderate levels of neutrality and their implications on the relationship between legal learning space and the graduates' preparedness for employment.

\section{Learning Space}

From the research investigation on the respondents' perceptions of learning space in preparing students for legal practice, it can be seen from Table 2, that there is a similar trend in terms of moderate levels of neutrality but lower levels of agreement to questions relating to the law course and its ability to prepare students for employment. None of the variables for age, gender and stage of academic development, which were tested for significance using multiple regression proved significant. 
Table 2

Statistics relating to perceptions of legal learning space and the role they play in legal understanding

\begin{tabular}{lccc}
\hline \multicolumn{1}{c}{ Question } & $\begin{array}{c}\text { Strongly agree/ } \\
\text { agree (\%) }\end{array}$ & Neutral (\%) & $\begin{array}{c}\text { Strongly } \\
\text { disagree/ } \\
\text { disagree (\%) }\end{array}$ \\
\hline $\begin{array}{l}\text { I enjoy the legal } \\
\text { learning space provided } \\
\text { in my law course }\end{array}$ & $51.9 \%$ & $25.0 \%$ & $23.1 \%$ \\
$\begin{array}{l}\text { Legal learning space has } \\
\text { given me an in-depth } \\
\text { understanding of legal } \\
\text { practice }\end{array}$ & $43.4 \%$ & $33.2 \%$ & $23.4 \%$ \\
$\begin{array}{l}\text { Legal learning space } \\
\text { allows me to apply what } \\
\begin{array}{l}\text { I have learned in my law } \\
\text { course }\end{array}\end{array}$ & & & \\
$\begin{array}{l}\text { I feel I have received } \\
\text { appropriate support } \\
\text { from using the learning } \\
\text { space }\end{array}$ & $55.9 \%$ & $28.5 \%$ & $15.6 \%$ \\
\hline
\end{tabular}

The majority of respondents were either indifferent or disagreed that they enjoyed the learning space which perhaps provided some insights into why many respondents did not feel that the learning space contributed to their employability. It has been argued in the literature that it is essential to make the pedagogy in teaching and learning engaging for its learners (Jones \& Iredale, 2010). If respondents did not enjoy the experience, it was likely that they felt it was not worthwhile and therefore did not engage them to get the full benefit of the learning space. A minority of the respondents felt that the experience gave them an in-depth understanding of legal practice which is of particular concern given that the purpose of the learning space is to encourage enhanced learning and the development of a wider skills set. The majority of the respondents did however feel that the learning space allowed them to apply what they had learned during their course and therefore felt that they had received appropriate levels of support. The reason why respondents 
were not particularly positive with regard to the learning space can perhaps be found in the qualitative component of this study, where respondents were asked to comment on learning space and what they enjoyed least about the learning space. The main themes which emerged were with regard to the lack of suitable learning space, the lack of suitable furniture and that the learning space did not fully replicate the real environment. The following were some of the responses:

\section{"when it comes to tutorial classes I feel like it's a normal classroom and not really effective." \\ "no[t] conducive and proper tables and chairs suited for a law student. Especially when intending to take notes and refer to laptop." \\ "the spaces are not a realistic representation of the practice of law."}

One response which summarised these themes was:

"It'snotconduciveforalaw student. Doesnotencourage learning or embody what a law student should expect in future career paths. It is a mere classroom which any student uses. Shows no resemblance to what a law student should expect in future law firm."

One respondent indicated that there was a lack of moot courts which was disappointing given that (as we will see in the next section) the majority of respondents thought the moot court replicated real legal practice and was in fact considered the most effective learning space in the law programme. The same respondent commented that:

\section{"It's only one room for mooting so it's difficult to train} moot."

What these results indicated is that having learning space did not necessarily make them effective in the eyes of the learner and that it is important to have the staff use the space as it is intended and consistently use appropriate space which is up-to-date (Kolb \& Kolb, 2005, 2010). The qualitative statements also provided some 
explanation as to why the respondents did not particularly enjoy the learning space. However, this study also elicited some interesting insights with regard to how students perceived the learning space. The majority of the respondents made reference to the aesthetics of the room, the ability to take notes and how the space did not replicate real legal practice which was a theme raised in the study by Daley and Sequeira (2018), where they argued that in order to replicate corporate space, students should physically work in that corporate space. Managing student expectations is vital. If students expect a replication of the real legal work environment they will assess a university learning space using this benchmark. Therefore universities should consider attaining more realistic student expectations or move towards integrating students into the work environment as part of every module and not simply rely on an internship or a simulated space. In the next section, the study will investigate perceptions of specific learning space and the role it plays in students' preparation for employment.

\section{Learning Space and Students' Ability to Replicate Real Legal Practice}

Similar moderate levels of neutrality were observed in this study which investigated the role of specific learning space in preparing students for legal practice. However, there were lower levels of agreement when compared with questions relating to the role of learning space in the respondents' enjoyment and understanding of their law course (Table 3). From the variables: age, gender and stage of academic development which were tested for significance using multiple regression, age proved significant, as most respondents who were older agreed to the statements. However, this did not mean that most of the alumni agreed to the statements. Alumni respondents were slightly more agreeable to statements concerning the effectiveness of learning space in replicating reality.

With the exception of moot court led activities, there were low levels of agreement to statements relating to the effectiveness of learning space to replicate real legal practice. These results are perhaps not surprising given the relatively low levels of agreement relating to 
Table 3

Statistics relating to perceptions of learning space replicating real legal practice

\begin{tabular}{|c|c|c|c|c|}
\hline Question & $\begin{array}{c}\text { Strongly } \\
\text { agree/agree } \\
(\%)\end{array}$ & $\begin{array}{l}\text { Neutral } \\
(\%)\end{array}$ & $\begin{array}{c}\text { Strongly } \\
\text { disagree/ } \\
\text { disagree } \\
(\%)\end{array}$ & $\begin{array}{c}\text { Significant } \\
\text { variables }\end{array}$ \\
\hline $\begin{array}{l}\text { Legal learning } \\
\text { space effectively } \\
\text { replicates the } \\
\text { reality of legal } \\
\text { practice }\end{array}$ & $35.6 \%$ & $32.0 \%$ & $32.4 \%$ & None \\
\hline $\begin{array}{l}\text { Legal learning } \\
\text { space does not ef- } \\
\text { fectively replicate } \\
\text { the reality of legal } \\
\text { practice }\end{array}$ & $41.0 \%$ & $30.1 \%$ & $29.0 \%$ & None \\
\hline $\begin{array}{l}\text { Virtual learning } \\
\text { space effectively } \\
\text { replicates the } \\
\text { reality of legal } \\
\text { practice }\end{array}$ & $33.6 \%$ & $41.4 \%$ & $25.0 \%$ & None \\
\hline $\begin{array}{l}\text { Augmented } \\
\text { reality learning } \\
\text { space effectively } \\
\text { replicates the } \\
\text { reality of legal } \\
\text { practice }\end{array}$ & $39 \%$ & $39.5 \%$ & $21.5 \%$ & None \\
\hline $\begin{array}{l}\text { Moot court } \\
\text { led activities } \\
\text { effectively } \\
\text { replicate the reality } \\
\text { of legal practice }\end{array}$ & $72.2 \%$ & $18.0 \%$ & $9.8 \%$ & None \\
\hline $\begin{array}{l}\text { Legal aid } \\
\text { centre activities } \\
\text { effectively } \\
\text { replicate the reality } \\
\text { of legal practice }\end{array}$ & $44.9 \%$ & $36.3 \%$ & $18.7 \%$ & Age $p<.001$ \\
\hline
\end{tabular}


respondents' enjoyment with the learning space and the qualitative statements regarding the look and feel of the learning space. An interesting result is that although $32.4 \%$ of the respondents disagreed that the learning space effectively replicated the reality of legal practice, only $41.0 \%$ of the respondents indicated that the learning space did not effectively replicate the reality of legal practice. This figure would have been higher if one third of the respondents disagreed that the learning space replicated real legal practice. Another surprising result was the low level of agreement for the statement concerning the legal aid centre. It has been argued in the literature that this platform bridges the gap between theory and practice (Lawton, 2017), giving the students real life experience with real clients (Trail \& Underwood, 1996). Findings from this study requires further investigation in a future study in order to understand why respondents had such low levels of agreement on this learning space which replicates real legal practice. A final result which requires further explanation was the low level of agreement relating to virtual learning and AR. Given that students will be graduating into a digital world where knowledge and application of that knowledge will be performed at least partially on a virtual platform, this study had expected higher levels of agreement to these statements. However, the explanation for this can perhaps be found in the qualitative statements where many respondents raised the issue of Wi-Fi and Internet connectivity, which have clear implications for the successful implementation of virtual learning.

\section{Learning Space and Developing Law Students' Hard Skills}

Having examined learning space and its capacity to replicate actual legal practice, this study went further to investigate whether learning space developed students' employability skills. In investigating its role in developing students' hard employability skills, a recurring theme surfaced in this study - relatively low levels of agreement, moderate levels of neutrality and some level of disagreement varying from low to moderate (Table 4). Based on the variables: age, gender and stage of academic development, which were tested for significance using multiple regression; only age proved significant, as respondents who were older agreed to the statements. As mentioned earlier, slightly more alumni respondents agreed and less disagreed to statements regarding the capability of learning space to improve students' employability skills. However, it cannot 
be stated that the older students were necessarily alumni as the older students were represented across all years of study.

Table 4

Statistics relating to harder skills effected by legal learning space

\begin{tabular}{|c|c|c|c|c|}
\hline Question & $\begin{array}{l}\text { Strongly } \\
\text { agree/agree } \\
(\%)\end{array}$ & $\begin{array}{c}\text { Neutral } \\
(\%)\end{array}$ & $\begin{array}{c}\text { Strongly } \\
\text { disagree/ } \\
\text { disagree } \\
(\%)\end{array}$ & $\begin{array}{l}\text { Significant } \\
\text { variables }\end{array}$ \\
\hline $\begin{array}{l}\text { Legal learning } \\
\text { space has improved } \\
\text { my project } \\
\text { management skills }\end{array}$ & $54.7 \%$ & $21.5 \%$ & $23.8 \%$ & None \\
\hline $\begin{array}{l}\text { Legal learning } \\
\text { space has improved } \\
\text { my communication } \\
\text { skills }\end{array}$ & $64.9 \%$ & $20.3 \%$ & $14.9 \%$ & None \\
\hline $\begin{array}{l}\text { Legal learning } \\
\text { space has improved } \\
\text { my creative } \\
\text { thinking skills }\end{array}$ & $44.9 \%$ & $27.7 \%$ & $27.3 \%$ & None \\
\hline $\begin{array}{l}\text { Legal learning } \\
\text { space has improved } \\
\text { my problem-solving } \\
\text { skills }\end{array}$ & $59.3 \%$ & $26.2 \%$ & $14.4 \%$ & None \\
\hline $\begin{array}{l}\text { Legal learning } \\
\text { space has improved } \\
\text { my leadership skills }\end{array}$ & $46.1 \%$ & $32.8 \%$ & $21.1 \%$ & Age $p<.007$ \\
\hline $\begin{array}{l}\text { Legal learning } \\
\text { space has improved } \\
\text { my teamwork skills }\end{array}$ & $71.9 \%$ & $16.4 \%$ & $11.8 \%$ & None \\
\hline
\end{tabular}

When the responses were considered collectively, with the exception of teamwork and communication skills, the levels of agreement to questions relating to the capacity of learning space to improve learners' hard skills were relatively low. Taking each of these results in turn, one of the reasons for lower levels of agreement towards these types of learning space to improve respondents' leadership 
skills could be because they preferred a career working for someone else rather than for themselves (Edwards \& Muir, 2012). It is arguable that working for a legal firm will require some degree of team leadership as it may also be that it requires less reliance on leadership skills. Equally, the reason for a lower level of agreement among respondents could be because they thought the space itself did not improve their leadership skills. Instead, it could be the nature of the assignment and collaboration with colleagues which could have more impact on this skill. Similarly, it could be argued that there were low levels of agreement to statements concerning the skills of creative thinking, problem-solving and project management because these skills were more related to the task or assignment rather than the learning space itself. However, it has been argued in the literature that collaborative classrooms can encourage an environment conducive to creativity and problem-solving. Therefore perhaps the respondents did not understand the role of the learning space in developing these skills or it is linked to the earlier qualitative statements regarding the respondents' perception of the facilities themselves and their appropriateness to learning (Wilders, 2017; Ellison, 2016; Seal, 2015; Cunningham \& Tabur, 2012; Pennington, 2012; Lippincott, 2010; Sullivan, 2010).

\section{Learning Space and Developing Law Students' Soft Skills}

Based on the study which investigated the role of learning space and the part they played in developing students' soft employability skills, it can be seen that levels of agreement were slightly higher here compared to the harder skills, with moderate levels of neutrality and some moderate levels of disagreement (Table 5). When the variables of age, gender and stage of academic development were tested, for significance using multiple regression none of them proved significant.

Developing graduates' softer skills set is considered important in today's disruptive employment market in order to compete against the advent of, for instance, AI. Therefore, it was encouraging to note that respondents perceived that the learning space had enhanced their skills of reflection, interpersonal interaction and confidence. It was to be expected that confidence had a higher level of agreement 
Table 5

Statistics relating to softer skills effected by legal learning space

\begin{tabular}{lccc}
\hline \multicolumn{1}{c}{ Question } & $\begin{array}{c}\text { Strongly } \\
\text { agree/agree } \\
(\%)\end{array}$ & $\begin{array}{c}\text { Neutral } \\
(\%)\end{array}$ & $\begin{array}{c}\text { Strongly disagree/ } \\
\text { disagree (\%) }\end{array}$ \\
\hline $\begin{array}{l}\text { Legal learning space has } \\
\text { improved my confidence }\end{array}$ & $56.6 \%$ & $39.3 \%$ & $14 \%$ \\
$\begin{array}{l}\text { Legal learning space } \\
\text { has improved my } \\
\text { interpersonal skills }\end{array}$ & $64.9 \%$ & $25.0 \%$ & $10.2 \%$ \\
$\begin{array}{l}\text { Legal learning space has } \\
\text { improved my ability to } \\
\text { reflect }\end{array}$ & $60.2 \%$ & $22.7 \%$ & $17.2 \%$ \\
\end{tabular}

given the level of public speaking involved in the course, particularly moot court related activities. Nevertheless, these findings supported existing studies (Jones \& Colwill, 2013; Draycott \& Rae, 2011; Birdthistle, Hynes, \& Fleming, 2007) on the importance of developing students' personal capabilities and indicated a positive response regarding the role of learning space in preparing students for the legal workplace.

A series of correlations were conducted using a Spearman's Rho test (Table 6) in order to test the strength and direction of association between two ranked variables, levels of student enjoyment and the various employability skills developed through the learning space. All of the correlations were statistically significant and positive with the strongest correlation between enjoyment and learning space capacity to encourage soft skills and reflection, with $r=0.530$, $\mathrm{p}<.01$. The fact that all the antecedent relationships with levels of enjoyment were statistically significant and positive indicated that learning space has a role to play in the development of a variety of hard and soft employability skills amongst the respondents. However, as revealed earlier in the results section, the respondents did not necessarily think that the legal learning space replicated the real legal environment. 
Table 6

Statistics relating to the relationship between legal learning spaces and improving employability skills

\begin{tabular}{|c|c|c|}
\hline & Correlation & Number \\
\hline $\begin{array}{l}\text { Enjoyment of the learning space and capacity of the } \\
\text { learning space to encourage the skills of reflection }\end{array}$ & $0.530 * *$ & 256 \\
\hline $\begin{array}{l}\text { Enjoyment of the learning space and capacity of the } \\
\text { learning space to encourage creative thinking skills }\end{array}$ & $0.481 * *$ & 256 \\
\hline $\begin{array}{l}\text { Enjoyment of the learning space and capacity of the } \\
\text { learning space to encourage critical thinking skills }\end{array}$ & $0.460 * *$ & 256 \\
\hline $\begin{array}{l}\text { Enjoyment of the learning space and capacity of the } \\
\text { learning space to improve confidence }\end{array}$ & $0.441 * *$ & 256 \\
\hline $\begin{array}{l}\text { Enjoyment of the learning space and capacity of the } \\
\text { learning space to improve problem-solving skills }\end{array}$ & $0.439 * *$ & 256 \\
\hline $\begin{array}{l}\text { Enjoyment of the learning space and capacity of the } \\
\text { learning space to improve project management skills }\end{array}$ & $0.435 * *$ & 256 \\
\hline $\begin{array}{l}\text { Enjoyment of the learning space and capacity of the } \\
\text { learning space to improve leadership skills }\end{array}$ & $0.402 * *$ & 256 \\
\hline $\begin{array}{l}\text { Enjoyment of the learning space and capacity of the } \\
\text { learning space to improve interpersonal skills }\end{array}$ & $0.392 * *$ & 256 \\
\hline $\begin{array}{l}\text { Enjoyment of the learning space and capacity of the } \\
\text { learning space to improve communication skills }\end{array}$ & $0.341 * *$ & 256 \\
\hline $\begin{array}{l}\text { Enjoyment of the learning space and capacity of the } \\
\text { learning space to improve teamwork skills }\end{array}$ & $0.330 * *$ & 256 \\
\hline
\end{tabular}

\section{CONCLUSION}

This study examined the role of legal learning space in a Malaysian university and how these simulated environments impacted on law students' preparedness for employment. It made the distinction 
between legal learning space, consolidating existing literature in the area of the graduate skills gap and preparing graduate employability skills set (Batt, 2015; Harrop \& Turpin, 2013; Rosenbaum, 2014; Stuckey, 2007; Sullivan, et al., 2007). This study also furthered research in terms of identifying students' perception on specific learning space and the employability skills they felt they developed while being engaged in such space.

The study found that students did not think that legal learning space at the university replicated real legal practice but thought that the space prepared them for employment. The students considered the moot court in particular to be the most effective space at developing their employability skills and enjoyed interacting with the space collectively. They felt that the space improved their teamwork and communication skills as well as their softer employability skills. These perceptions could be that mooting requires students to argue on fictitious lawsuits before practitioners/lawyers who sit in as judges. Thus this space replicates an environment akin to a court room setting which requires students to be well-prepared for their 'case' and to think on their feet when addressing questions raised by the 'court'. The moot court setting challenges the students' ability to manage their prepared arguments as a team against those raised by their opponents on the other side of the case. In such an environment, students will be able to hone their advocacy, articulation and quick thinking skills and also improve their patience, poise and confidence when arguments are not in their favour. This will benefit and prepare students for the rigours that come their way during employment, especially as legal practitioners, which as a result will enhance their chances of employability.

This study also revealed that the perceptions of legal learning space could be improved with better management of staff and student expectations. Although the stage of academic development was not found to be significant it cannot be underestimated that limited engagements with available learning space had an impact on the findings. Limited engagements with moot court activities, legal aid centres and AR perhaps did not expose students to the benefits of the learning space as much as could be possible. It is acknowledged, however, that many students did indicate that regardless of the number of times they were exposed to such learning space they felt that the space did not replicate the real legal environment and 
therefore, direct engagements with law offices as part of each module or at least some modules, could be the way forward to address this observed limitation in university practice-based curricula.

There were several limitations in this study. First, it was only confined to law students at a university. Even though this was not considered a major limitation given that the study was on law students in particular and that this study formed the initial part of a larger study involving a number of Malaysian institutions. This study was representative of the law student population of the university and as facilities were replicated at other Malaysian universities the findings were deemed to be generalisable. The second limitation was the sample size; although it was representative of the student cohort at the university, this study would have benefitted from including more alumni respondents, as only $43(17 \%)$ responded Another possible limitation was the lack of a qualitative dimension beyond including open-ended questions. As mentioned, such limitations were addressed in the larger study which, was to build on themes which emerged from this study so as to take the research forward regarding the role of learning space in preparing law graduates for the workplace.

With regard to further studies, the researchers intend to undertake a wider study across other Malaysian universities to investigate commonalities and themes to enable the findings to be more readily generalised. In terms of further research themes, it proposes to investigate and compare perspectives from various stakeholders: law staff from Malaysian universities, employers and students, with perspectives from those who are currently studying at universities and with those who have graduated and currently employed. Gaining the perspectives of all these stakeholders could provide a more holistic view of legal learning space and the role it plays in developing employability skills among graduates and preparing them for the future employment market.

\section{ACKNOWLEDGEMENTS}

The authors of this study would like to thank all law students and the alumni for their participation in the study. A special mention and thanks to Azrahani Abdul Halim for being of invaluable assistance 
to the authors. The authors would also like to thank the committee members of Taylor's Teaching and Learning Conference 2018 and the support staff of Taylor's University for their assistance. This study received no specific grant from any funding agency—-public, commercial or non-profit.

\section{REFERENCES}

Amirnuddin, P. S. (2018). Redesigning Formative Assessments for land law using AR. In Ghaffar, F. A., \& Yusop, F. D. (Eds.), Redesigning assessment for holistic learning: A quick guide for Higher Education. ADEC: University of Malaya Press.

Azuma, R. (1997). A survey of augmented reality. Presence: Teleoperators and Virtual Environments, 6(4), 355-385.

Babacan, A., \& Babacan, H. (2015). A transformative approach to work integrated learning in legal education. Education + Training, 57(2), 170-183.

Baker, D. (2017). The End of Wisdom? The Future of Libraries in the Digital Age. Amsterdam: Elsevier Ltd.

Batt, C. (2015). Integrating Experiential Education into the Law School Curriculum. Elon Law Review, 7, 43-56.

Beard, D., Schwieger, D., \& Surendran, K. (2007). Incorporating soft skills into accounting and MIS curricula. In Proceedings of the 2007 ACM SIGMIS CPR conference on 2007 computer personnel doctoral consortium and research conference: The global information technology workforce. ACM, 179-185.

Birdthistle, N., Hynes, B., \& Fleming, P. (2007). Enterprise education programmes in secondary schools in Ireland: A multi-stakeholder perspective. Education + Learning, 49(4), 265-276.

Breen, J. M. (2005). Justice and Jesuit Legal Education: A Critique. LOY. U. CHI. L.J, 36, 383.

Bucholtz, B. K., Frey, M. A., \& Tatum, M. L. (2002). The Little Black Book: A Do-It-Yourself Guide for Law Student Competitions. Durham DC: Carolina Academic Press.

Bos, N., Groeneveld, C., van Bruggen, J., \& Brand-Gruwel, S. (2015). The use of recorded lectures in education and the impact on lecture attendance and exam performance. British Journal of Educational Technology, 47(5), 906-917. 
Carmigniani, J., \& Furht, B. (2011). Augmented Reality: An Overview. In B. Furht (Ed.), Handbook of Augmented Reality. New York, NY: Springer.

Churchill, G. A., Jr. (1991). Marketing Research: Methodological foundations (5th ed.). Hinsdale: The Dryden Press.

Clarke, M. (2016). Addressing the soft skills crisis. Strategic HR Review. 15(3), 137-139.

Clarke, M. (2009). Understanding and managing employability in changing career contexts. Journal of European Industrial Training, 32(4), 258-284.

Cunningham, H., \& Tabur, S. (2012). Learning space attributes: Reflections on academic library design and its use. Journal of Learning Spaces, 1(2), 1-6.

Daley, P., \& Sequeira, I. (2018). Digital Transformation at the New York Times: The Usefulness of the Live Case Intervention Method. In Turner, J. J. \& Mulholland, G. (Eds.), International Enterprise Education: Perspectives on Theory and Practice. London: Routledge.

Danielson, J., Preast, V., Bender, H., \& Hassall, L. (2014). Is the effectiveness of lecture capture related to teaching approach or content type? Computers \& Education, 72, 121-131.

Department for Business Innovation \& Skills (2015), Entrepreneurship skills: Literature and policy review, [online]. BIS Research Paper, 236, 1-50.

Draycott, M. C., \& Rae, D. (2011). Enterprise education in schools and the role of competency frameworks, International Journal of Entrepreneurial Behaviour \& Research, 17(2), 127-145.

Edwards, L. J., \& Muir, E. J. (2012). Evaluating enterprise education: Why do it? Education + Training, 54(4), 278-290.

Ellison, W. (2016). Designing the learning spaces of a university library. New Library World, 117(5/6), 294-307.

Elyna, M. N., \& Pitt, M. (2014). Facilities management in Malaysia. Facilities, 32, 490-508.

Fiala, N., Gertler, P., \& Carney, D. (2014). The role of hard and soft skills in entrepreneurial success: Experimental evidence from Uganda. AEA RCT Registry, November 07.

Fitzgerald, J. E., White, M. J., W., T. S., Maxwell-Armstrong, C. A., \& James, D. K. (2008). Are we teaching sufficient anatomy at medical school? The opinions of newly qualified doctors. Clinical Anatomy, 21(7), 718-724. 
Forum, W. E. (2016). The future of jobs employment, skills and workforce strategy for the fourth industrial revolution. Retrieved June 3, 2018, from http://www3.weforum.org/ docs/WEF_Future_of_Jobs.pdf

Galloway, L., Marks, A., \& Chillas, S. (2014). The use of internships to foster employability, enterprise and entrepreneurship in the IT sector. Journal of Small Business and Enterprise Development, 21(4), 653-667.

Ghosh, P. (2017). The innovative data scientist: Overcoming the big data and data management divide. Dataversity. Retrieved from: http://www.dataversity.net/innovative-data-scientistovercoming-big-data-data-management-divide/.

Gurpur, S., \& Rautdesai, R. (2014). Revisiting legal education for human development: Best practices in South Asia. Procedia Social and Behavioral Sciences, 157, 254-265.

Harrop, D., \& Turpin, B. (2013). A study exploring learners' informal learning space behaviors, attitudes, and preferences. New Review of Academic Librarianship, 19, 58-77.

Hensler, D. R. (2018). Reconstructing big law: The big picture. In M. Gómez \& R. Pérez-Perdomo (Eds.), Big law in Latin America (p. 327). Switzerland: Palgrave Macmillan. https:// doi.org/https://doi.org/10.1007/978-3-319-65403-4_11

Jameson, A., Carthy, A., McGuinness, C., \& McSweeney, F. (2016). Emotional intelligence and graduates - employer's perspectives. Procedia - Social and Behavioural Sciences, 228, 515-522.

Jones, P. \& Colwill, A. (2013). Entrepreneurship education: An evaluation of the Young Enterprise Wales initiative. Education + Training, 55(8/9), 911-925.

Jones, B. \& Iredale, N. (2010), Enterprise education as pedagogy, Education + Training, 52(1), 7-19.

Joseph, R. P., Jessop, T., Okafor, G., Almpanis, T., \& Price, D. (2018). Big brother or harbinger of best practice: Can lecture capture actually improve teaching? British Educational Research Journal, 44(3), 377-392.

Joy, P. A. (2018). The uneasy history of experiential education in U.S. law schools. Penn State Law Review, 122, 551-583.

Kahn, L. B. (2017). Demand for social and cognitive skills is linked to higher firm productivity. Yale Insights. Retrieved March 8 2018, from: http://insights.som.yale.edu/insights/demandfor-social-and-cognitive-skills-is-linked-to-higher-firmproductivity 
Kent, R. (1999). Marketing Research: Measurement, Method and Application. London: International Thomson Business Press.

King, M., \& Newman, R. (2009). Evaluating business simulation software: Approach, tools and pedagogy. On The Horizon, 17(4), 368-377.

King, M. R. N., Dawson, R. J., Rothberg, S. J., \& Batmaz, F. (2017). Utilizing a realist evaluative research approach to investigate complex technology implementations. Journal of Systems and Information Technology, 19(1/2), 22-41.

Klopfer, E. \& Squire, K. (2008). Environment detectives: The development of an augmented reality platform for environmental simulations. Educational Technology Research and Development, 56(2), 203-228.

Knemeyer, D. (2015). Design thinking and UX: Two sides of the same coin. Interactions. Retrieved from: http://interactions. acm.org/archive/view/september-october-2015/designthinking-and-ux

Kolb, A.Y., \& Kolb, D. A. (2005). Learning styles and learning spaces: Enhancing experiential learning in higher education. Academy of Management Learning and Education, 4(2), 193-212.

Kolb, A. Y. \& Kolb, D. A. (2010). Learning to play, playing to learn: Case study of a ludic learning space. Journal of Organizational Change Management, 23(1), 26-50.

Krupová, T., Pošíková, L., Friedel, T., \& Potucký, J. (2013). Do moot courts belong to high schools? And if so, under what circumstances? International Journal of Clinical Legal Education, 19, 405-412.

Lawton, J. D. (2017). Teaching Social Justice in Law Schools: Whose Morality is it? Indiana Law Review, 50(3), 813-847.

Lippincott, J. (2010). Information commons: Meeting millennials' needs. The Journal of Library Administration, 50, 27-37.

McGivern, Y. (2003). The practice of market and social research. London: Prentice Hall.

Malhotra, N. K., \& Birks, D. F. (2006). Marketing Research: An applied approach. (2nd European ed.). Essex: Pearson Education Limited.

Mangan, D. (2017). Lawyers could be the next profession to be replaced by computers. Retrieved from: http:www.cnbc. com/2017/02/17/lawyers-could-be-replaced-by-artificalintelligence.html 
Matamoros, A. B. (2015). Answering the call: Flipping the classroom to prepare practice-ready attorneys. Capital University Law Review, 43, 113-151.

National Center for O*NET Development for USDOL. (2017). The O*NET Content Model. $O * N E T$ Resource Centre. Retrieved from: https://www.onetcenter.org/content.html

Newton, G. Tucker, T. Dawson, J, \& Currie, E. (2014). Use of lecture capture in higher education-Lessons from the trenches. TechTrends, 58(2), 32-45.

Ng, A. Y. H, Lim, C. L., \& Nair, P. K. (2014). X-Space Model: Taylor's University's collaborative classroom design and process. Procedia-Social and Behavorial Sciences, 123, 272279.

Nokelainen, P., Nevalainen, T., \& Niemi, K. (2018). Mind or Machine? Opportunities and Limits of Automation. In S. Billett, C. Harteis, \& H. Gruber (Eds.), The Impact of Digitalization in the Workplace: An Educational View. Springer International Publishing AG. https://doi.org/ttps:// doi.org/10.1007/978-3-319-63257-5_2

Oskamp, A., \& Lodder, A. (2006). Introduction: Law, Information Technology, and Artificial Intelligence. Netherlands: Springer.

Owston, R., Lupshenyuk, D., \& Wideman, H. (2011). Lecture capture in large undergraduate classes: Student perceptions and academic performance. The Internet and Higher Education, 14(4), 262-268.

Pennington, T. M. (2012). Third space: Creating a library environment that opens doors for collaboration, value, and student achievement. Retrieved from: http://centralspace. ucmo.edu/xmlui/bitstream/handle/10768/119/TPennington_ LIBRARYSCIENCE.pdf? sequence $=1$

Rajeswaran, R. (2006). Legal Education in ASEAN in the 21st Century. ASEAN Law Association 9th General Assembly, Bangkok. Retrieved from: http://www.aseanlawassociation. org/9GAdocs/w2_Malaysia.pdf

Rao, M. S. (2014). Enhancing employability in engineering and management students through soft skills. Industrial and Commercial Training, 46(1), 42-48.

Rao, M. S. (2013). Blend hard and soft skills to fast-track a management career. Human Resource Management International Digest, 21(7), 3-4. 
Renganathan, S., Karim, Z. A. B. A., \& Li, C. S. (2012). Students' perception of industrial internship programme. Education +Training, 54(2/3), 180-191.

Rosenbaum, S. A. (2014). Beyond the fakultas' four walls: Linking education, practice and the legal profession. Pacific Rim Law \& Policy Journal, 23, 395-421.

Ruan, N. (2014). Student, Esquire?: The Practice of Law in the Collaborative Classroom. Clinical Law Review, 20(2), 429465.

Rubenson, K. (2005). Social class and adult education policy. New Directions for Adult \& Continuing Education, 106, 15-25.

Sail, R. M., \& Alavi, K. (2010). Social skills and social values training for future k-workers. Journal of European Industrial Training, 34(3), 226-258.

Scott, C. L. (2015). The futures of learning 3: What kind of pedagogies for the 21st century? Education, Research and Foresight, Working Papers, 8.

Seal, R. A. (2015). Library spaces in the 21st century: Meeting the challenges of user needs for information, technology, and expertise. Library Management, 36(8/9), 558-569.

Serin, H. (2017). Augmented technologies in the education: AR apps. Journal of Educational Sciences and Psychology, 7(2), 4-16.

Singh, P., Narasuman, S., \& Thambusamy, R. X. (2012). Refining teaching and assessment methods in fulfilling the needs of employment: A Malaysian perspective. Futures, 44(2), 136147.

Stigliani, I. (2017). Design thinking - The skill every MBA student needs. The Financial Times. Retrieved March 102018 from: https://www.ft.com/content/cbf70424-422a-11e7-82b6896b95f30f58

Stuckey, R. (2007). Best practices for legal education: A vision and a road map (1st ed.). USA: Clinical Legal Education Association.

Sullivan, R. (2010). Common knowledge: Learning spaces in academic libraries. College and Undergraduate Libraries, $17(2 / 3), 130-148$.

Sullivan, W. M., Colby, A., Wegner, J. W., Bond, L., \& Shulman, L. S. (2007). Educating lawyers: Preparation for the profession of law (1st ed.). San Francisco: Jossey-Bass. 
Schwab, K. (2016). The fourth industrial revolution: What it means and how to respond. Retrieved from: https://www.weforum. org/agenda/2016/01/the-fourth-industrial-revolution-what-itmeans-and-how-to-respond/

Taylor, B. F. (2015). Through the looking glass: Perceptions on the Law school learning experience. Loyola Law Review, 61, 276-297.

Teply, L. L. (2003). Law school competitions in a nutshell. St Paul, MN: Thomson/West.

Trail, W. R., \& Underwood, W. D. (1996). The decline of professional legal training and a proposal for its revitalization in professional law schools. Baylor Law Review, 48, 201-222.

Turner, J. J., Goh, S. K., Beard, C., \& Mulholland, G. (forthcoming in 2018). A Business Simulation Game (BSG) and its ability to enhance learning: An evaluation of student perspectives. In Mulholland, G. \& Turner, J. J. (Eds.), Enterprise education in UK Higher Education: Challenges for theory and practice. London: Routledge.

Turner, J. J., \& Mulholland, G. (2017). Enterprise education: Towards a framework for engaging with tomorrow's entrepreneurs. Journal of Management Development, 36(6), 1-18.

Vos, L., \& Brennan, R. (2010). Marketing simulation games: Student and lecturer perspectives. Marketing Intelligence \& Planning, 28(7), 882-897.

Wilders, C. (2017). Predicting the role of library bookshelves in 2025. The Journal of Academic Librarianship, 43(5), 384391.

Witton, G. (2017). The value of capture: Taking an alternative approach to using lecture capture technologies for increased impact on student learning and engagement. British Journal of Educational Technology, 48(4), 1010-1019.

Yusof, N., Awang-Hashim, R., \& Kian, C. K. (2016). Investigating learning space for research workspaces in high education in Malaysia. Malaysian Journal of Learning and Instruction, 13(2), 201-226.

Zikmund, W. G. (2003). Business research methods. London: Thomson/South-Western. 